\title{
Nyevangelismen set med danske øjne
}

Dansk nyevangelisme i teologihistorisk perspektiv

\author{
Førsteamanuensis dr.theol. \\ Finn Aa. Rønne, Fjellhaug International University \\ College-Denmark
}

\begin{abstract}
Whereas the so-called "New-Evangelicalism" ("Nyevangelismen") is a well-known phenomenon in Swedish revival history and has drawn much attention in Swedish church history scholarship, it has gone relatively unnoticed in a Danish context. This article focuses on the question: What is New-Evangelicalism from a Danish point of view? The question is addressed primarily within the discipline of Historical Theology and in relation to soteriology. "New-Evangelicalism" is defined as the revival movement closely associated with the Swedish author, C.O. Rosenius (1816-1868). The article argues that New-Evangelicalism is characterized by a tension between pietism and moravianism, not least with regard to soteriological issues. This has resulted in different versions of the movement depending on whether the previous religious environment was dominated by either pietism or moravianism. It is also shown that the relation between pietism and moravianism in the local versions of New-Evangelicalism is expressed through their position on the doctrine of universal justification.
\end{abstract}

Keywords: Pietism - Moravianism - C.O.Rosenius - Denmark - Bornholm - Norway - doctrine of universal justification - revivalism New-Evangelicalism - Sweden.

Der har i de senere år været et par organisationsjubilæer i det kirkelige Danmark, som ikke har påkaldt sig megen opmærksomhed uden for egne kredse, men hvor der ikke desto mindre er tale om to organisationer, som kan siges at være de danske repræsentanter for en betydelig kirkelig og teologisk bevægelse i det skandinaviske vækkelsesmiljø, nemlig den såkaldte nyevangelisme. Det er Luthersk Mission (LM), som fyldte 150 år i 2018, og den noget mindre Evangelisk Luthersk Missionsforening (ELM), der opstod som en splittelse af LM for godt 125 år siden.

Nyevangelismen er et relativt ukendt begreb i dansk sammenhæng. Begrebet er opstået i forbindelse med skandinavisk, især svensk, vækkelseshistorie fra 1800-tallet og frem, som betegnelse for en strømning i de skandinaviske vækkelsesmiljøer. I de andre skandinaviske lande, ikke mindst i Sverige, har nyevangelismen de sidste 200 år været et markant indslag i kirkelivet, og selvom bevægelsen ikke er så 
kendt i Danmark, finder man forbindelser til og indflydelse fra nyevangelismen i så forskelligartede retninger som Indre Mission, den tidlige grundtvigianisme og Tidehverv. ${ }^{1}$

Nyevangelismen har haft nogle fremtrædende talsmænd og været ophav til og præget en række organisationer. Grundlæggende er der imidlertid tale om en strømning. Dermed er den sværere at få hold på og beskrive - i alt fald teologisk. På den anden side er det netop noget af det, som gør nyevangelismen interessant, da man ved at beskæftige sig med den kommer i berøring med mange dele af skandinavisk kirkeliv de sidste 200 år.

Nyevangelismen har imidlertid været forholdsvis upåagtet også $\mathrm{i}$ den teologiske forskning i Danmark. Det er baggrunden for, at denne artikel vil fokusere på nyevangelismen ud fra en dansk synsvinkel. Samtidig vil perspektivet primært være teologihistorisk: Hvad kendetegner den danske - og til dels norske - nyevangelisme som teologihistorisk fænomen?

Kirkehistorisk set er nyevangelismen opstået i sammenhæng med 1800-tallets kulturelle og samfundsmæssige udvikling i Skandinavien, hvor ikke mindst relationen til de skandinaviske stats- og folkekirkesystemer har haft stor betydning for bevægelsens opkomst og udvikling. ${ }^{2}$ Dermed vil en kirkehistorisk undersøgelse af nyevangelismen aktualisere vigtige ekklesiologiske overvejelser. ${ }^{3}$ Denne artikels teologihistoriske perspektiv vil imidlertid på en særlig måde bringe soteriologien - frelsens tilvejebringelse og modtagelse - i fokus.

\section{Nyevangelismen i forskningen}

Der er ikke i den skandinaviske vækkelsesforskning fuldstændig enighed om definitionen og karakteristikken af nyevangelismen.

1. Finn Aa. Rønne, "Rosenianismen i Danmark", Carl Olof Rosenius. Teolog, författare, själavårdare, red. LarsOlov Eriksson \& Torbjörn Larspers, bd. 74, Skrifter utgivna av Svenska kyrkohistoriska föreningen, II ny följd (Skellefteå: Artos \& Norma Bokförlag 2016), 141-57.

2. Af nyere fremstillinger se især: Anders Jarlert, Sveriges kyrkohistoria. 6. Romantikens och liberalismens tid, (Stockholm: Verbum 2001), 152-59; Oloph Bexell, Sveriges kyrkohistoria. 7. Folkväckelsens och kyrkoförnyelsens tid (Stockholm: Verbum 2003), 37-68; Stefan Gelfgren, Ett utvalt släkte. Väckelse och sekularisering - Evangeliska Fosterlands-Stiftelsen 1856-1910 (Skellefteå: Norma 2003), 40-63; Martin Berntson, Bengt Nilsson \& Cecilia Wejryd, Kyrka i Sverige: introduktion till svensk kyrkohistoria (Skellefteå: Artos \& Norma, 2012), 262-64.

3. Se fx Mikkel Vigilius, Kirke i kirken: Luthersk vakkelses-kristendom - fra kirkelig bevagelse over organisation til kirkeligt opbrud (Hillerød: LogosMedia 2005), 117-27. 
Et af de seneste danske forskningsbidrag, som behandler nyevangelismen, er Elith Olesens doktordisputats fra 1996: De frigjorte og trellefolket. ${ }^{4}$ Elith Olesen fører oprindelsen tilbage til den tidlige svenske herrnhutisme omkring midten af 1700-tallet, med tætte forbindelser til stifteren, Zinzendorf selv, og anser den radikale herrnhutiske præst Anders Carl Rutström (1721-1772) for at være nyevangelismens stamfader. Dermed bliver nyevangelismen kendetegnet af en radikal, meget anti-pietistisk herrnhutisk teologi. Samtidig fremhæves den svenske vækkelsesprædikant og forfatter Carl Olof Rosenius (18161868) som den, der på en særlig måde har videreført indflydelsen fra Rutström og været årsag til nyevangelismens udbredelse, først i Sverige og siden i de andre skandinaviske lande. Fokus i Olesens afhandling er den angelsaksiske "Revival and Holiness Movement" fra sidste halvdel af 1800-tallet og dens indflydelse i Danmark. Derfor sættes nyevangelismen i relation til denne bevægelse, idet Olesen peger på træk ved teologien hos både Zinzendorf og de forskellige repræsentanter for nyevangelismen, som han mener har beredt vejen for "Holiness-bevægelsen".

En helt anden teologihistorisk placering af nyevangelismen finder vi i dele af den norske kirkehistorieforskning. Her anser man nyevangelismen for at være en videreudvikling og samtidig radikalisering og afsporing af den bevægelse, Carl Olof Rosenius var ophav til. Det er grundigt behandlet af Godvin Ousland, der i Vekkelsesretninger i norsk kirkeliv meget betegnende har et kapitel med overskriften "Fra rosenianisme til nyevangelisme". ${ }^{5}$ Samme definition af nyevangelisme findes i et jubilæumsskrift for LM's norske - ligeledes rosenianske - søsterorganisation, Norsk Luthersk Misjonssamband: "Nyevangelismen forbindes helst med antinomisme og verdensrettferdiggjørelseslæren. Og Rosenius stod ikke for noen av delene. Derfor bør ikke Rosenius kalles nyevangelist." ${ }^{6}$ Nyevangelismen beskrives her med træk fra en ensidig, radikaliseret herrnhutisme, og dermed ligger denne definition af nyevangelismen indholdsmæssigt tæt på Elith Olesens.

Der findes imidlertid også i norsk sammenhæng andre definitioner af nyevangelismen. I sin meget kortfattede fremstilling af C.O. Rosenius' indflydelse i Norge behandler Einar Molland rosenianismen og nyevangelismen under ét. Det siges ikke direkte, at de er identiske,

4. Elith Olesen, De frigjorte og trellefolket: Amerikansk-engelsk indflydelse på dansk kirkeliv omkring år 1900 (København: ANIS $\left.{ }^{1} 1996\right), 168-220$.

5. Godvin Ousland, Vekkelsesretninger i norsk kirkeliv 1840-75: hva de larte og siktet på (Oslo: Luther 1978), 93.

6. Erik Kjebekk, Verden for Kristus. Norsk Luthersk Misjonssamband 1891-1991. Heimearbeidet (Oslo: Lunde forlag 1991), 44. 
men der skelnes på den anden side ikke mellem dem. ${ }^{7}$ Noget lignende gør sig gældende for Oftestad, Rasmussen og Schumachers kirkehistorie. $^{8}$

Uanset definitionen af nyevangelismen er der dog i skandinavisk sammenhæng enighed om, at bevægelsen stammer fra Sverige og på en eller anden måde er relateret til Carl Olof Rosenius. Derfor er det også i Sverige, vi finder den mest omfattende forskning i nyevangelismens historie. Denne forskning gives der en gennemgang af i en af de mest grundige fremstillinger af nyevangelismen: Konrad Stormarks En for alle og alle i en: blad fra nyevangelismens historie og teologi. ${ }^{9}$ Trods nuancer i opfattelsen hos de svenske forskere er de fleste enige om at se Carl Olof Rosenius som bevægelsens centrale skikkelse. Det er mest tydeligt hos Hjalmar Holmquist, der finder nyevangelismens "dogmatiske genesis i Rosenius' omvendelseskamp og hans vei fram til klarhet" (Stormark 1981, 31). Konrad Stormark følger i sin afhandling linjen fra Holmquist og de andre svenske forskere. Det samme gælder nyere fremstillinger af Anders Jarlert (Jarlert 2001), Oloph Bexell (Bexell 2003) og Stefan Gelfgren (Gelfgren 2003). Derfor er det også den definition og karakteristik, jeg vil gå ud fra i denne artikel.

Det skal samtidig nævnes, at "nyevangelisme" i Finland betegner en særlig finsk retning (Stormark 1981, 37, 227-339). Den har ganske vist forbindelse til C.O. Rosenius og den skandinaviske nyevangelisme, men har svensk-finnen F.G. Hedberg (1811-1893) som sin ophavsmand og repræsenterer et i forhold til den skandinaviske nyevangelisme - sådan som den defineres i denne artikel - mere entydigt herrnhutisk fænomen, og derfor ligger den teologisk tættere på nyevangelismen, som den defineres af Olesen og Ousland.

Karakteristik af nyevangelismen som teologihistorisk fænomen

I Bengt Hägglunds klassiske teologihistorie finder vi en meget præcis definition af nyevangelismen:

7. Einar Molland, Norges kirkehistorie i det 19. århundre, bd. II (Oslo: Gyldendal Norsk Forlag 1979), 114.

8. Bernt T. Oftestad, Tarald Rasmussen \& Jan Schumacher, Norsk kirkehistorie (Oslo: Universitetsforlaget 1991).

9. Konrad Stormark, En for alle og alle i en: blad fra nyevangelismens historie og teologi (Oslo: Luther Forlag 1981), 29-37. 
Den s. k. nyevangeliska rörelse är i Sverige knuten till C.O. Rosenius' namn ... Denne anknyter i sin förkunnelse fremför allt till Luther och har tagit arv av den inomkyrkliga pietismen och av herrnhutismen, som hade ett starkt fäste i den bygd i Norrland, där han växte upp. Men han har därjämte stått under inflytande av samtida metodistisk och reformert förkunnelse. ${ }^{10}$

Det er den definition, jeg vil gå ud fra. Den fremstiller, i lighed med Hjalmar Holmquist og andre svenske forskere, direkte nyevangelismen som den bevægelse i skandinavisk kirkeliv, der er udgået fra C.O. Rosenius. Det er ham, som er ophav til den, og gennem det, han har skrevet, er den blevet spredt ud over Skandinavien. Derfor må bevægelsens teologiske karakteristika også findes i forlængelse af C.O. Rosenius' egen teologi. Vi definerer altså nyevangelismen både ud fra de faktisk forekommende grupper, som står i traditionen fra Rosenius, og ud fra nogle bestemte teologiske kendetegn, nemlig det som på en særlig måde karakteriserer Rosenius' teologi.

Samtidig er det vanskeligt at komme med en helt præcis og entydig fremstilling af teologien inden for nyevangelismen. I første omgang fordi teologien hos Rosenius selv er karakteriseret af nogle spændinger, betinget af hans teologiske baggrund, de påvirkninger han var udsat for i løbet af livet, og de personer og teologiske retninger han måtte forholde sig til. Det har så i næste omgang fremkaldt nogle spændinger i den nyevangeliske tradition efter Rosenius og betydet, at nyevangelismen har antaget forskellige former, med forskellig teologisk profil, afhængig af det teologiske miljø, den har fremtrådt i forskellige steder i Skandinavien.

Hägglund nævner 5 forskellige inspirationskilder til Rosenius' teologi:

1. "Frem for alt" Luther. Indflydelsen fra Luther ligger ligesom i bunden af Rosenius' teologi. Det er frem for alt hos ham, Rosenius i tillæg til Skriften - har hentet byggestenene til sin teologi. Og det er ham, der står som den vigtigste teologiske autoritet for Rosenius. ${ }^{11}$ Det fremgår ikke mindst af en artikel af Flemming Kofod-Svendsen,

10. Bengt Hägglund, Teologins historia: en dogmhistorisk översikt (Lund: LiberLäromedel 1978), 366.

11. Her følger jeg Hägglund, Holmquist (Hjalmar Holmquist, Handbok $i$ svensk kyrkohistoria III (Stockholm 1953), 69) og hovedparten af de svenske forskere. I modsætning til Elith Olesen, som mener, at Rosenius var herrnhutisk frem for luthersk, og at hans mange henvisninger til Luther primært er der for at give hans synspunkter legitimitet (Olesen 1996, 174-78) - "bevidst iscenesat" af en "durkdreven" Rosenius. 
der har kortlagt alle de steder, hvor der er henvist til eller anvendt noget af Luther, i samtlige årgange af Rosenius' tidsskrift Pietisten. ${ }^{12}$

2. og 3. Dernæst nævnes to retninger inden for lutherdommen, der har været særligt betydningsfulde som baggrund for Rosenius' teologi og forkyndelse: Pietismen og herrnhutismen. De skal derfor behandles udførligt nedenfor, idet det samtidig skal relateres til den grundlæggende indflydelse fra Luther. Det sker som sagt med et fokus på soteriologien.

4. og 5. Endelig peges der på to retninger fra angelsaksisk hold, metodismen og reformert kristendom, som også har øvet indflydelse på Rosenius. Det er dog sket i langt mindre grad, hvorfor vi ikke vil behandle det grundigere i denne sammenhæng.

For at forstå nyevangelismens særlige teologiske kendetegn inden for skandinavisk lutherdom, er det altså vigtigt at fokusere på pietismen og herrnhutismen, som på basis af Luther selv på en særlig måde har formet den nyevangelisme, som udgik fra Rosenius. Ofte betragtes de to strømninger som nært beslægtede vækkelsesretninger - hvad de da også er, både i deres oprindelse og fortsatte udvikling, ikke mindst set $\mathrm{i}$ forhold til andre teologiske retninger. I forhold til nyevangelismen og det, som karakteriserer den bevægelse, er det imidlertid de indbyrdes forskelle - og i visse henseender modsætninger og brydninger - som er vigtige at få frem. Det er forskelle og brydninger, som går tilbage til Zinzendorf selv (Olesen 1996, 81-87). Og det er det, som har fremkaldt de spændinger, som er karakteristisk både for Rosenius' og nyevangelismens teologi.

\section{Pietismen}

Pietismen har helt fra begyndelsen været kendetegnet af en vægtlægning på den personlige - i den forstand subjektive - og den erfaringsmæssige side af kristendommen. Man har understreget vigtigheden af, at der sker en personlig tilegnelse af de objektive realiteter, der er det, Kristus har tilvejebragt gennem sit liv, sin død og sin opstandelse. Og den tilegnelse skal ske gennem en sand omvendelse og en levende tro, der medfører en reel forvandling og fornyelse af mennesket med konkrete udslag i det praktiske liv. Det er der så i teologien og forkyndelsen sket en konkret, erfaringsbaseret udmøntning af. Vejen til en sand og levende tro er blevet fastlagt i forskellige stadier gennem den såkaldte ordo salutis (salighedens orden). Hvert stadium repræsenterer en sjælstilstand med bestemte kendetegn, som man kan prøve sig selv

12. Flemming Kofod-Svendsen, "Rosenius som bruger og formidler af Luther", Dansk Tidsskrift for Teologi og Kirke 44 (2017), 249-69. Se også Flemming Kofod-Svendsen, "Carl Olof Rosenius' teologi med særligt henblik på hans kirkesyn", Dansk Teologisk Tidsskrift 79 (2016), 22-40. 
på for at finde ud af, hvor i denne udvikling man befinder sig. Selve troen kan også konstateres gennem særlige kendetegn, som man kan spejle sig i og prøve sig på. Det kommer fx til udtryk i Erik Pontoppidans Troens Spejl, som spillede en central rolle ved C.O. Rosenius' omvendelse. På samme måde bliver også de konsekvenser, omvendelsen og troen skal have, konkretiseret gennem praktiske leveregler.

Alt dette har givet pietismen et subjektivistisk præg med en udbredt tilbøjelighed til introspektion. Det har medført et problem i forhold til menneskets vished om personlig frelse. Visheden er i alt fald delvis blevet grundet på resultatet af selvprøvelsen og er derved gjort usikker. I nogle pietistiske retninger har man oven i købet fremhævet uvisheden som normalsituationen.

\section{Herrnhutismen}

Der, hvor herrnhutismen har udviklet sig i en reaktion på pietismen, har den kraftigt betonet Kristi stedfortrædende straflidelse som grundlag for menneskets frelse og det bibelske vidnesbyrd som basis for visheden om den personlige delagtighed heri. Som reaktion på pietismens subjektive orientering har man altså vist væk fra mennesket og i stedet fremhævet de objektive realiteter: det, som allerede er bragt i stand i og med Kristi død på korset. Til trods for dette finder man, ikke mindst hos stifteren Zinzendorf og i den tidlige herrnhutisme, stærke subjektivistiske tendenser. Det skyldes en fremhævelse af den følelsesmæssige oplevelse af fællesskab med Kristus i hans lidelser, som opnås ved indgående betragtning af hans blodige død på korset. Dette moment er imidlertid senere blevet kraftigt nedtonet - og de objektive elementer tilsvarende styrket - i de dele af herrnhutismen, som er blevet mere præget af luthersk teologi (Gelfgren 2003, 46). Det gælder fx i det nordsvenske vækkelsesmiljø, som nyevangelismen omkring C.O. Rosenius udsprang af. Alligevel spores påvirkningen fra herrnhutismen ofte, ved at temaer i relation til "blodet" og "sårene" optræder hyppigt i forkyndelsen af og sange om Kristi stedfortrædende lidelse og død.

Pietismen og herrnhutismen kom med udgangspunkt i Tyskland til at gå som sideløbende strømninger i de skandinaviske vækkelsesbevægelser. Nogle gange prægede de hver sine bevægelser, der da kom til at stå $\mathrm{i}$ et modsætningsforhold til hinanden. I andre tilfælde løb de sammen i én bevægelse og var her en kilde til indre brydninger. Begge dele ses i og omkring den nyevangeliske bevægelse. 
Rosenius i spændingen mellem pietisme og herrnhutisme ${ }^{13}$

Hägglund nævner, at pietismen og herrnhutismen havde et stærkt tag i det nordsvenske vækkelsesmiljø, hvor Rosenius voksede op. Det var altså herigennem, at han i første omgang blev præget af henholdsvis pietismen og herrnhutismen. ${ }^{14}$

Vækkelsesfolket i Nordsverige gik under betegnelsen "læsere". De var delt i to retninger: "gammellæserne" og "nylæserne". Gammellæseriet, der havde rødder tilbage til midten af 1700-tallet, var meget pietistisk præget. Nylæseriet opstod langt på vej som en reaktion på dette og var tydelig herrnhutisk orienteret - samtidig med at det var præget af en udbredt læsning af Luthers skrifter (Gelfgren 2003, 46; Kofod-Svendsen 2017, 253; Jarlert 2001, 152). Rosenius kom selv fra nylæserkredsene. Det er derfor naturligt, at han fra starten har været meget influeret af en herrnhutisme, der var grundlæggende formet af luthersk teologi. Han har imidlertid også i det nordsvenske vækkelsesmiljø modtaget påvirkning fra en mere pietistisk inspireret kristendomsforståelse. Dertil kommer, at han allerede tidligt har haft en noget kritisk distance til visse elementer i herrnhutismen.

Dette er dernæst blevet forstærket gennem den litteratur, Rosenius brugte og blev præget af. Her finder vi en stor mængde pietistisk orienterede opbyggelsesbøger, hvor Erik Pontoppidans forfatterskab indtager en særstilling. At det var en passage fra Pontoppidans bog Troens Spejl, der var den direkte årsag til Rosenius' åndelige gennembrud, fik varig betydning for hans forhold til pietismen og dermed for hele hans kristendomssyn, hvor forholdet mellem den sande og den falske tro og vigtigheden af selvprøvelse står centralt. Ellers er det bemærkelsesværdigt, at de forfattere, der har haft særlig stor betydning for Rosenius, som regel har stået for et moderat pietistisk eller herrnhutisk syn.

Spændingen mellem pietismen og herrnhutismen kom også til udtryk gennem en række forhold i Rosenius' samtid, således at han ved flere lejligheder oplevede sig placeret i denne spænding. Det blev særlig tydeligt, når han blev ført ud i debatter, hvor han måtte gå imod personer på begge fløje. Ofte fremstiller han to "afveje" - en "lovisk"15

13. Fremstillingen i dette kapitel sker primært på baggrund af Finn Rønn Pedersen, C.O.Rosenius og laren om universel retfardiggørelse. Larte C.O.Rosenius verdensretfardiggørelse? Haggamal 6 (København 1990), 97-104.

14. Se også Berntson, Nilsson \& Wejryd (2012), 263.

15. Termen "lovisk" findes ikke i det danske sprog, men har karakter af terminus technicus i nyevangeliske kredse, også i Danmark. Her har ordet ofte en negativ klang, idet det betegner en sammenblanding af lov og evangelium, hvor det grundlæggende i kristendommen bliver de fordringer, som på forskellige områder stilles 
og en "evangelisk", hvorefter han gør rede for den middelvej, han selv ønsker at følge. Oprindelig bekæmpede han den "loviske afvej”, der kom til udtryk gennem en forkert anvendelse af den pietistiske ordo salutis, nemlig der hvor den ikke bare bruges deskriptivt, men også præskriptivt (se nedenfor). Han blev både af sig selv og sin samtid betragtet som herrnhuter. Det blev imidlertid snart klart for ham, at også herrnhutismen kunne føre uheldige ting med sig, som det var nødvendigt at advare imod. Han reserverer sig ikke mindst over for de tilspidsede herrnhutiske udtryk, der på en for ensidig måde fremhæver evangeliets objektive og universelle karakter, således at det fører til ligegyldighed i forhold til omvendelsen, troen og det kristne liv.

Det samme kommer frem, hvis man betragter Rosenius' forkyndelse ud fra denne synsvinkel. Særligt i den første tid er den helt klart bestemt af en herrnhutisk reaktion imod en, som Rosenius ser det, "pietistisk loviskhed". Han taler til mennesker, der er bundet af ordo salutis-skemaets krav om bestemte sjælstilstande på vejen mod en sand tro og er fikseret i en introspektiv søgen efter de rette virkninger. Over for disse forkyndes på herrnhutisk vis et betingelsesløst evangelium om Kristi fuldbragte værk: "Alt er færdigt og klart til at modtage - for intet. Kom som du er!" (Jarlert 2001, 154-55). Samtidig er der imidlertid også tydelige pietistiske træk. Rosenius understreger betydningen af, at man har erfaret en levende tro, der medfører en forvandling og et nyt liv. Der er en gennemgående selvransagende tone og en fremhævelse af "troens kendetegn". Typisk pietistisk er også den efterhånden stærkere vægtlægning på nødvendigheden af omvendelse, troens personlige tilegnelse og det kristne livs udfoldelse i tjeneste for Gud og mennesker.

Når Rosenius selv placerer sig i en midterposition mellem pietismen og herrnhutismen, er det en følge af, at han er meget opmærksom på den aktuelle situation i vækkelsesmiljøet og behovene hos tilhørerne. Det gør, at han har forståelse for og selv i sin lære og forkyndelse er bestemt af hovedmotiverne bag såvel pietismen som herrnhutismen, dvs. både ser behovet for at fremhæve nødvendigheden af omvendelse, tro og et helligt liv (pietismens hovedmotiv), og - for at give den troende fred, vished og frimodighed - ønsker at vise væk fra mennesket selv til det, som Jesus har fuldbyrdet én gang for alle (herrnhutismens hovedmotiv).

Den til dels modsatrettede påvirkning fra pietismen og herrnhutismen har - sammen med den tidligere nævnte indflydelse fra metodismen og reformert kristendom - givet nogle spændinger i Rosenius'

til mennesket. Hvis man vil bruge en mere neutral betegnelse, kan termen "lovagtig" anvendes. 
teologi og forkyndelse, som også har bevirket, at man vanskeligt kan tale om en kohærent teologi hos Rosenius. Dette har så videre fået konsekvenser for den nyevangelisme, Rosenius blev ophav til.

\section{Nyevangelismen i spændingen mellem pietisme og herrnhutisme}

Fra Rosenius og med hans skriftlige produktion, som næsten udelukkende stammer fra det blad, Pietisten, han udgav, er nyevangelismen blevet spredt ud over Skandinavien. Og med indflydelsen fra Rosenius og nyevangelismen er også fulgt en påvirkning fra både pietismen og herrnhutismen, ligesom den beskrevne spænding mellem pietisme og herrnhutisme har gjort sig gældende mange steder. Når den pietistiske og herrnhutiske indflydelse - og spændingen mellem de to retninger - gennem Rosenius og nyevangelismen er nået ud til forskellige kredse i Skandinavien, er det sket i et møde med vækkelsesmiljøer, som i forvejen har været påvirket af pietismen og herrnhutismen - på forskellige måder. Og det har bevirket, at Rosenius-receptionen har fået forskellig karakter, og nyevangelismen også har udviklet sig forskelligt i forskellige dele af Skandinavien. I Rosenius' teologi og forkyndelse finder vi som sagt både pietistiske og herrnhutiske elementer - og en spænding mellem dem. Når så indflydelsen fra Rosenius og nyevangelismen er nået ud i de forskellige miljøer, er resultatet blevet, at forholdet mellem de pietistiske og herrnhutiske elementer i den lokale nyevangelisme er blevet forskellig fra sted til sted.

Det vil jeg her give eksempler på fra to dele af Skandinavien: Norge og Bornholm.

\section{Norge}

I Norge oplevede man også i løbet af 1800-tallet store vækkelser, først med udgangspunkt i Hans Nielsen Hauges virksomhed og siden omkring Gisle Johnson. Begge vækkelser var pietistisk orienteret med vægt på bod, omvendelse og et nyt og anderledes liv. De norske vækkelsesbevægelser havde imidlertid oplevet, hvad Stormark kalder en “evangelisk klargjøring” (Stormark 1981, 44), allerede inden nyevangelismen kom til Norge. Denne "klargjøring" skete i 1830-erne og 1840-erne, hvor haugianske prædikanter kom til at lægge mere vægt på det objektive i kristendommen - forsoning og retfærdiggørelse end de havde gjort tidligere. Derfor var vækkelsesbevægelserne i Norge "i stand til å tilpasse seg nyevangelismen eller assimilere det beste $\mathrm{i}$ den” (Stormark 1981, 45). Det bevirkede på den anden side, at bortset 
fra nogle få, ret isolerede kredse, som blev meget profileret herrnhutiske (og som ser ud til at have haft en vis kontakt med den markant herrnhutiske organisation, Evangelisk Luthersk Missionsforening i Danmark), bevarede også de vækkelseskredse, som var blevet påvirket af nyevangelismen, et grundlæggende pietistisk præg. ${ }^{16}$ Selv på steder, hvor nyevangelismen fik meget stærkt indpas, lykkedes det at integrere denne bevægelse i den gamle pietistiske/haugianske retning.

Vi ser altså, at balancen mellem de pietistiske og herrnhutiske elementer i den norske nyevangelisme - på grund af det miljø, som nyevangelismen her mødte - tippede lidt til den pietistiske side. Det kom bl.a. til udtryk i omvendelsesforkyndelsen, som også i rosenianske kredse fokuserede på den enkeltes egen beslutning og afgørelse i forbindelse med omvendelsen. Og det har så i næste omgang påvirket Luthersk Missionsforening i Danmark, som har hentet megen inspiration fra Norge.

\section{Bornholm}

Bornholm står centralt, når det gælder den danske nyevangelisme, ikke mindst fordi den første nyevangeliske organisation, Luthersk Mission, opstod på Bornholm. Det kommer fx til udtryk ved, at et teologisk standardværk som Realencyklopädie für protestantische Theologie und Kirche behandler nyevangelismen under opslaget "Die Bornholmer" ${ }^{17}$ Medlemmer af Luthersk Mission og Evangelisk Luthersk Missionsforening er da også i det øvrige Danmark ofte gået under navnet "Bornholmerne" - uafhængig af deres tilknytning til øen.

Ligesom i resten af Danmark virkede der i løbet af 1700-tallet flere pietistiske præster på Bornholm, men som det skete mange andre steder, døde den pietistiske vækkelse snart ud. Kirkelivet var ved århundredeskiftet meget præget af rationalismen, og det fortsatte det med at være til langt ind i det 19. århundrede. Først i 1860'erne kom de folkelige vækkelser for alvor til Bornholm. Den centrale skikkelse var her bornholmeren P.C. Trandberg, der i 1860 vendte tilbage til sin fødeø som kapellan efter studier i København og et kortvarigt virke i Jylland. Han virkede både som fast kapellan og omrejsende forkynder og blev ophav til en meget omfattende, udpræget pietistisk vækkelse på øen. Hans bods- og vækkelsesforkyndelse, der vendte sig imod rationalismen i kirken og verdsliggørelsen i de enkelte menne-

16. Jeg takker dosent emeritus Erik Kjebekk, Fjellhaug internasjonale Høgskole, for at have gjort mig opmærksom på disse forhold.

17. Realencyklopädie für protestantische Theologie und Kirche, bd. 3 (Leipzig 1897), 326-29. 
skers liv, havde en stærk effekt, og Trandberg fik mange tilhængere over hele Bornholm. ${ }^{18}$

Den bornholmske vækkelse oplevede imidlertid snart en dybtgående splittelse. Et stort flertal af dens tilhængere fulgte en af Trandbergs medarbejdere, smeden Christian Møller, da han brød med Trandberg og dannede Luthersk Missionsforening til Evangeliets fremme i Danmark (LM), der efterhånden udbredte sin virksomhed til mange dele af Danmark (Pedersen 2018, 18-20, 29-30). Senere, omkring 1890, blev LM selv splittet i to, og de medlemmer, som skilte sig ud, dannede Evangelisk Luthersk Missionsforening (ELM).

I et bind af Bornholmske Samlinger, udgivet af Bornholms historiske Samfund, behandler docent Rune Söderlund, Teologiska Institutionen ved Lunds Universitet, ovenstående hændelsesforløb under overskriften "Svensk evangelisk väckelse på Bornholm" ${ }^{19}$ Her forklarer han netop udviklingen ud fra det, han beskriver som den grundlæggende teologiske forskel og spænding mellem pietismen og herrnhutismen. Nogle oplevede angiveligt, at de ikke fik fred og vished gennem Trandbergs pietistiske bods- og vækkelsesforkyndelse med dens stadige krav om ændringer, som måtte ske med den enkelte $\mathrm{i}$ form af anger, bod, omvendelse, tro og en ny, anderledes livsførelse. Derfor førte det til splittelse, da Chr. Møller - og i næste omgang mange andre gennem hans forkyndelse - på herrnhutisk vis i stedet fik fremhævet, at alt det, som blev krævet af dem, allerede var bragt i orden i og med Jesu liv, død og opstandelse. Efter nogle år oplevede Chr. Møller og andre ledere i LM, at denne vægtlægning på "det allerede fuldbyrdede" kunne føre til sløvhed og ligegyldighed (Olesen 1996, 212-20). Da de som en konsekvens heraf begyndte at lægge vægt på formaningerne til et helligt liv, førte det igen til en splittelse af vækkelsesmiljøet omkring LM, som nu var blevet udbredt til både Sjælland og Jylland. Denne udvikling i Chr. Møllers og andres teologi og forkyndelse hang imidlertid ikke bare sammen med en iagttagelse af situationen blandt vækkelsesfolket, men skete også som følge af en påvirkning fra den angelsaksiske "Holiness-movement" - en påvirkning som ikke bare førte til en anderledes vægtlægning i teologi og forkyndelse, men også til en markant anderledes teologi på bestemte punkter (ibid.).

Det, som i begge tilfælde - $\mathrm{i}$ alt fald delvis - ligger til grund for splittelsen, kan ses som en herrnhutisk reaktion på en pietistisk forkyndelse. Vi ser altså, hvordan de spændinger mellem pietisme og

18. Birger Pedersen, Bornholmerne - de satte prag på Luthersk Missions forste 150 år (Fredericia: Logos Media 2018), 12-17.

19. Rune Söderlund, "Svensk evangelisk väckelse på Bornholm”, Bornholmske Samlinger III. række, bd. 14 (2000), 143-54. 
herrnhutisme, der som beskrevet karakteriserede det svenske vækkelsesmiljø omkring nyevangelismen, med den blev overført til Danmark, hvor man hidtil ikke havde oplevet de samme brydninger mellem de to retninger. Da LM kort tid efter sin oprettelse startede virksomhed omkring Skjern i Vestjylland, kom man hurtigt til at stå i et modsætningsforhold til det pietistiske Indre Mission, og i den forbindelse møder vi de samme diskussioner om, hvor meget der er fuldbyrdet henholdsvis står tilbage for os mennesker, når det gælder vores frelse. ${ }^{20}$

Vi ser også, hvordan balancen mellem de pietistiske og herrnhutiske elementer i den lokale nyevangelisme tipper til den herrnhutiske side, når nyevangelismen hos Chr. Møller og i LM møder et stærkt pietistisk miljø, som den kommer til at stå i et modsætningsforhold til. Det samme sker for den nyevangelisme, som vi finder i ELM, fordi den fremkommer som resultat af en reaktion på en øget pietistisk orientering i LM - der er blevet yderligere forstærket gennem en påvirkning fra den angelsaksiske "Holiness-movement".

\section{Nyevangelismen og læren om universel retfærdiggørelse}

Noget, som har fulgt nyevangelismen gennem hele dens historie, har været en debat om det, man plejer at kalde verdensretfærdiggørelseslæren - eller læren om universel retfærdiggørelse (LUR). ${ }^{21}$ Det har fx været tilfældet i relationen mellem LM og den gruppe, som brød ud og dannede ELM (Rønn Pedersen 1990, 17-18). Vi ser også flere eksempler på det i både Sverige og Norge - og Finland for den sags skyld. Det er derfor nærliggende at tænke, at netop debatten om universel retfærdiggørelse kan være med til at belyse fænomenet nyevangelisme.

Læren om universel retfærdiggørelse har ofte været udtrykt gennem en enkelt linje fra en svensk herrnhutisk sang: Verden i Jesus retferdig er vorden. En mere udviklet teologisk definition kan formuleres således: Hvert menneske er som person, direkte og uden begronsning, genstand for den retfardiggørelse og tilgivelse, som er knyttet til Kristus $i$ hans død og opstandelse, og det fremsattes derfor som et almengyldigt

20. Luthersk Missionsforening 1868 - 1918 Mindeblade. Skrevet af nogle af Foreningens Venner (Rønne: Luthersk Missionsforenings Forlag 1922), 127.

21. Se fx Olesen (1996), 51, 168-220. 
udsagn og et fuldbyrdet faktum, at alle - i en vis forstand ${ }^{22}$ - personligt er retfardiggjort og har syndernes forladelse.

Hvis man undersøger de debatter om LUR, som er foregået i forskellige sammenhænge, viser det sig, at debatterne ofte har været et vigtigt element netop i brydningen mellem henholdsvis en pietistisk og en herrnhutisk kristendomsforståelse. I denne brydning har LUR på den ene side ofte været udtryk for en herrnhutisk reaktion på elementer i pietismen. ${ }^{23}$ Over for pietismens fremhævelse af det, som må ske med og gennem det enkelte menneske, har man med LUR tværtimod villet fremstille, hvordan alt det afgørende allerede er sket i og med Jesu død og opstandelse - også menneskets retfærdiggørelse og tilgivelsen af dets synder. På den anden side har en modstand mod LUR ofte været et resultat af en pietistisk reaktion på elementer i en herrnhutisk kristendomsforståelse. Man har frygtet, at betoningen af, at alt er fuldbyrdet i og med Jesu død og opstandelse, vil føre til negligering af nødvendigheden af en sand omvendelse, en levende tro, og et nyt, forvandlet liv. Og derfor har man især vendt sig imod den fremhævelse af, at alt det afgørende allerede er sket i og med Jesu død og opstandelse, som LUR er udtryk for.

Da vi her har at gøre med strømninger, der som beskrevet er en vigtig del af nyevangelismen, kan debatten om LUR være med til at vise os, hvordan en pietistisk og en herrnhutisk kristendomsforståelse har forholdt sig til hinanden inden for nyevangelismen. Holdningen til LUR siger tydeligvis noget om, hvilken side - pietisme og herrnhutisme - man hælder til, og på den måde kan LUR i nyevangeliske kredse være en indikator på, hvordan forholdet mellem de pietistiske og herrnhutiske elementer er i en given sammenhæng. Det vil vi se nogle eksempler på - hos Rosenius selv, og igen fra Norge og Bornholm.

\section{C.O. Rosenius'syn på laren om universel retferdiggørelse}

C.O. Rosenius er ofte blevet inddraget i debatterne om LUR. Gang på gang er noget af det, han har skrevet, blevet citeret, og man har påberåbt sig hans autoritet. Som noget meget bemærkelsesværdigt har både tilhængere og modstandere af LUR søgt støtte hos C.O. Rose-

22. Det er vigtigt at bemærke, at den lære om universel retfærdiggørelse, vi møder inden for nyevangelismen, adskiller sig fra det, vi finder hos fx Karl Barth (Karl Barth, Die kirchliche Dogmatik. Vierter Band. Die Lehre von der Versöhnung. Erster Teil (Zürich 1953), 634-36, 835-37.) Som læren er udformet inden for nyevangelismen, er den ikke ensbetydende med en apokatastasislære. Troen er fortsat nødvendig for at få gavn af retfærdiggørelsen og syndsforladelsen.

23. Hos Zinzendorf fremtræder LUR fx som en tydelig antipietistisk reaktion (Leiv Aalen, Den unge Zinzendorfs teologi (Oslo: Lutherstiftelsens Forlag 1952), 309-10; Stormark 1981, 11, 24 og 66). 
nius - og det i lige høj grad for begge parters vedkommende (Rønn Pedersen 1990, 25-26).

Nyere forskning har påvist, hvordan Rosenius indtager en midterposition i debatten om LUR - og at det er noget af forklaringen på, at han er blevet taget til indtægt for begge syn (Rønn Pedersen 1990, 163-164): På den ene side tager han gennem hele sin virksomhedsperiode principielt afstand fra LUR - sådan som den er defineret ovenfor. På den anden side kan han, ikke mindst i sammenhæng med den praktiske forkyndelse og sjælesorg, udtrykke sig på en måde, som isoleret betragtet er ensbetydende med en lære om universel retfærdiggørelse. Det er samtidig dette, som har været med til at give de spændinger i hans teologi og forkyndelse, som der tidligere er redegjort for - og som formodentlig også er årsag til, at han er blevet taget til indtægt for to helt modsatrettede syn.

Rosenius sætter selv debatten om LUR i relation til spændingen mellem pietisme og herrnhutisme, idet han flere steder ved sin behandling af LUR henviser til den overordnede diskussion vedrørende herrnhutismen og pietismen og gør opmærksom på, at LUR i brydningen mellem en pietistisk og en herrnhutisk kristendomsforståelse er blevet en slags parole, der viser, hvad man ønsker at stå for. Det er også tydeligt, at den midterposition, han personligt indtager i debatten om LUR, netop svarer til hans position mellem en pietistisk og en herrnhutisk kristendomsforståelse, hvor man i hans teologi og forkyndelse finder en spænding mellem pietistiske og herrnhutistiske elementer:

Han tager afstand fra visse udformninger af en herrnhutisk forkyndelse - og går ikke ind for LUR. Hans principielle afvisning af LUR er selvfølgelig bibelsk og dogmatisk begrundet, men den hænger desuden nok så meget sammen med de uheldige virkninger, han mener, læren har haft på forkyndelsen og fromhedslivet. Her er der netop tale om de samme uheldige forhold, som Rosenius mente herrnhutismen i visse tilfælde kunne føre med sig, og som gjorde ham skeptisk til træk ved nogle herrnhutiske retninger: ligegyldighed i forhold til omvendelsen, troen og det kristne liv.

På den anden side kan han i mødet med det, han ser som negative konsekvenser af pietismen, selv i sin forkyndelse formulere sig på en måde, der kan være eller isoleret betragtet direkte er ensbetydende med en lære om universel retfærdiggørelse. I de tilfælde, hvor hovedmålgruppen har behov for at få fremhævet, at der ret beset ikke er nogen krav, de skal opfylde for at blive frelst, men at alt er fuldbyrdet, kan han i sin forkyndelse lade det ubetinget og uden begrænsning omfatte alle, som egentlig ifølge hans eget principielle syn kun gælder dem, der tror. Ud fra et principielt synspunkt kan man forudsætte 
de forbehold, som kommer eksplicit frem andre steder i Rosenius' fremstillinger, men i den praktisk-pastorale situation udelades de af hensyn til modtagernes situation.

\section{Synet på laren om universel retfardiggørelse}

$i$ det norske vakkelsesmiljø

At holdningen til LUR kan sige noget om forholdet mellem de pietistiske og herrnhutiske elementer i en given sammenhæng kommer også tydeligt frem i forbindelse med udviklingen i Norge, hvor vi har set, at også vækkelseskredse, der blev påvirket af nyevangelismen, bevarede deres grundlæggende pietistiske præg. I overensstemmelse hermed møder vi netop der en næsten entydig afstandtagen til verdensretfærdiggørelseslæren. Det ser vi fx tydeligt hos en meget roseniansk teolog som kirkehistorikeren Carl Fredrik Wisløff (1908-2004), der også argumenterer for, at Rosenius var klart imod verdensretfærdiggørelseslæren. ${ }^{24}$ Det kommer endvidere frem i den norske oversættelse af den husandagtsbog, som blev lavet med stykker fra Pietisten. I andagten til den 31. marts finder vi et af de steder hos Rosenius, som isoleret betragtet giver udtryk for verdensretfærdiggørelse. Her hedder det i den første norske oversættelse udgivet af Chr. Dick i 1876, helt i overensstemmelse med det svenske forlæg: ${ }^{25}$

Se da her: Denne Syndsforladelse, denne Forløsning, som nu er nævnt, den tilhører hvert Menneske, godt og ondt, troende og vantro. Du vare, hvordan du vil, saa er i det mindste dine Synder borttagne, udslettede, forladte, kastede i Havets Dyb - dette skede i Kristi Dødstime. Bliver du fordømt, saa sker det ikke for dine Synder, men for din Vantro, din Bortebliven. Vil du igjen komme til Gud, blive hans egen og have hans Naade, saa er intet til Hinder, du er hver Stund kjærkommen [mine fremhævelser]

Sådan er formuleringen også i de næste 3 oplag fra 1876 og 1877. Men så i et oplag, som udkommer i 1887, og hvor oversætteren ikke er angivet, er det ændret til: ${ }^{26}$

24. Carl Fredrik Wisløff, "Rosenius og læren om verdens-rettferdiggjørelse. Lærte Rosenius at folk ligger i helvete med tilgitte synder?", Fast Grunn 1949, nr. 2 (1949), 96-104.

25. Husandagtsbog. Betragtninger for hver Dag i Aaret af C.O. Rosenius. Udgivet paa Norsk af Chr. Dick (Bergen: Forlagt af F. Beyer 1876).

26. Husandagtsbog. Betragtninger for hver Dag i Aaret af C.O. Rosenius. Udgivet i Oversættelse. 5. oplag (Bergen: Forlagt af F. Beyer 1887). 
Betænk altsaa dette: Denne Syndsforladelse, denne Forløsning, som her er omtalt, den tilhører hvert eneste Menneske, hvad enten han er from eller ugudelig, troende eller vantro. Du maa vare, hvordan du vare vil, saa er der dog engang skeet en fuld Forsoning for dine Synder - dette skeede i Kristi Dødsstund. Bliver du fordømt, saa sker det ikke for dine Synders Skyld, men for din Vantros Skyld, fordi du bliver borte fra Kristus. Vil du komme tilbage til Gud, blive hans egen og eie hans Naade, saa er der intet til hinder, du er naarsomhelst velkommen [mine fremhævelser]

Der er altså foretaget en rettelse, så det ikke længere er udtryk for verdensretfærdiggørelse. Siden er der udkommet mange udgaver af husandagtsbogen på norsk, og de følger alle oversættelsen fra 1887. Formodentlig for at holde afstand til læren om den universelle retfærdiggørelse.

\section{Laren om universel retfardiggørelse i LM og ELM}

Også i forbindelse med den teologiske udvikling i tilknytning til LM og ELM, ser vi tydeligt, at holdningen til LUR bliver en indikator på, hvilken side - pietisme og herrnhutisme - man hælder til, og hvordan forholdet mellem de pietistiske og herrnhutiske elementer er.

Christian Møller blev en ivrig fortaler for LUR i den periode, hvor der hos ham fremkom en stærk herrnhutisk præget reaktion imod den pietistiske teologi og forkyndelse hos Trandberg og hos de repræsentanter fra Indre Mission, han mødte rundt omkring i Danmark. ${ }^{27}$ På den anden side var kritik af Chr. Møller i mange tilfælde bestemt af pietistiske anliggender, og det kom bl.a. til udtryk netop gennem en afvisning af LUR. Da Trandberg reagerede på Møllers herrnhutisk bestemte kritik af hans egen tidligere (og implicit Trandbergs) pietistisk prægede forkyndelse, var det fx Møllers manglende forståelse for helliggørelsen - og hans lære om universel retfærdiggørelse, kritikken på en særlig måde rettede sig imod. ${ }^{28} \mathrm{Og}$ når Asschenfeldt-Hansen, ud fra sin pietistiske synsvinkel, hos Rosenius og især Møller savner syn for helliggørelsen og Guds buds fortsatte betydning for den kristne, kombineres det også med, at LUR fremhæves som en særlig problematisk side ved Chr. Møllers teologi og forkyndelse. ${ }^{29}$

Noget lignende gør sig gældende i forbindelse med ELM's forhold til LM. En væsentlig årsag til splittelsen af LM og dannelsen af ELM var som nævnt en herrnhutisk præget reaktion mod en stærkere vægt-

27. Chr. Møller, "Om Faldet i Adam og Opreisningen i Christo", Budskab fra Naadens Rige 3, nr. 9-11 (1867), 129-58, 161-73.

28. P.C. Trandberg, Aabent Sendebrev til Udgiveren af "Budskab fra Naadens Rige" (Kjøbenhavn 1866), 36-37.

29. C. Asschenfeldt-Hansen, Kirkehistorie for Menigheden II (1908), 492-508. 
lægning på pietistiske anliggender i forkyndelsen hos nogle ledende i LM. ${ }^{30}$ Vi har ikke sikre vidnesbyrd om, at selve læren om universel retfærdiggørelse i så høj grad var til debat i forbindelse med splittelsen, men den blev efterfølgende af ELM gjort til et af hovedpunkterne i forskellen mellem LM og ELM - netop som et konkret udtryk for en herrnhutisk orienteret teologi og forkyndelse i ELM til forskel fra det, man så som en pietistisk "afsporing" i LM (Mindeskrift for Evangelisk-Luthersk Missionsforening paa Bornholm 1942, 20-26, 61). På den anden side får vi i årene efter splittelsen for første gang fra ledere i LM en eksplicit afstandtagen til LUR, som vi ser i et svarskrift, der især rettede sig mod Asschenfeldt-Hansens angreb på LM. ${ }^{31}$

Ligesom i Norge er der også i Danmark eksempler på, at man forandrer en gammel tekst, der har været set som udtryk verdensretfærdiggørelse, for at markere en afstandtagen til LUR - og måske også som indikation på en ændret balance mellem de pietistiske og herrnhutiske elementer i den aktuelle version af nyevangelismen.

Som nævnt er læren om universel retfærdiggørelse ofte blevet udtrykt gennem en enkelt linje fra en svensk herrnhutisk sang: Verden $i$ Jesus retferdig er vorden. Der er tale om første linje i et vers af sangen, "Åbent står Jesu forbarmende hjerte".

I mange år fastholdt man i både LM's og ELM's sangbøger den oprindelige ordlyd: Verden i Jesus retferdig er vorden. I ELM var det et led i fremhævelsen af læren om universel retfærdiggørelse, mens der i LM ikke sjældent blev gjort opmærksom på, at der burde have stået "forsonet" i stedet for "retfærdig". Og da der i 1993 kom en ny udgave af LM's sangbog, var sanglinjen gengivet: Verden i Jesus forsonet er vorden. Det er derfor interessant at se, hvilken version som blev valgt, da LM og ELM i 2013 var fælles om udgivelsen af en ny sangbog. At ELM accepterede, at det blev "forsonet" i stedet for "retfærdig", kan tages som udtryk for, at man ikke længere lægger så meget vægt på læren om universel retfærdiggørelse, eller at man - i alt fald for nogles vedkommende - helt har forladt den. En artikel af ELM's landssekretær, Peder Østergaard Jensen, viser, at begge dele er tilfældet. ${ }^{32} \mathrm{Og}$ det kan hænge sammen med en udvikling i forholdet mellem de pietistiske og herrnhutiske elementer i den teologi og forkyndelse, vi møder i

30. Mindeskrift for Evangelisk-Luthersk Missionsforening paa Bornholm (Rønne 1942), 14-21.

31. Luthersk Missionsforening, Vort Svar paa Asschenfelt Hansens Angreb paa Luthersk Missionsforening i "Kirkehistorie for Menigheden" (Rønne: P. Møllers Bogtrykkeri 1911), 53.

32. Peder Østergård Jensen, "En sanglinje med konsekvenser", Liv i troen 2014, nr. 3 (2014), 6-8. 
ELM's nuværende version af nyevangelismen, med en større forståelse for de pietistiske anliggender.

\section{Konklusion}

Hvad kendetegner nyevangelismen som teologihistorisk fænomen? Det er det spørgsmål, denne artikel har søgt at besvare - primært ud fra en dansk/norsk synsvinkel.

Nyevangelismen er - ikke mindst teologihistorisk i relation til soteriologien - kendetegnet af en spænding mellem en pietistisk og en herrnhutisk kristendomsforståelse. Og forholdet mellem de herrnhutiske og de pietistiske elementer i lokale udgaver af nyevangelismen har været forskelligt fra sted til sted, afhængig af om det vækkelsesmiljø, hvor nyevangelismen fremtrådte, i udgangspunktet var pietistisk eller herrnhutisk domineret - og af hvordan nyevangelismen reagerede på dette.

Vi har endvidere set, hvordan forholdet mellem de pietistiske og herrnhutiske elementer i en given udgave af nyevangelismen afspejles i en stillingtagen til læren om universel retfærdiggørelse, som til stadighed har været til debat inden for nyevangelismen.

Det er de forhold, som også gør sig gældende omkring de to danske repræsentanter for nyevangelismen, Luthersk Mission og Evangelisk Luthersk Missionsforening, som begge for nylig har fejret deres jubilæer. Som det fremgår af navnet på den forening, der blev resultatet af en brydning inden for dansk nyevangelisme mellem en pietistisk og en herrnhutisk kristendomsforståelse - og som vi også så i forbindelse med Rosenius' placering i spændingen mellem pietisme og herrnhutisme - bliver det sat i relation til den lutherske dialektik mellem "lov" og "evangelium". Det kan ses som udtryk for, at det er inden for skandinavisk lutherdom - på basis er luthersk teologi - nyevangelismen har udviklet sig som et særligt fænomen. 
